\title{
Erratum
}

\section{Interleukin-6 Upregulates Neuronal Adenosine Al Receptors: Implications for Neuromodulation and Neuroprotection}

Knut Biber, A Pinto-Duarte, MC Wittendorp, AM Dolga, CC Fernandes, J Von Frijtag Drabbe Künzel, JN Keijser, R de Vries, AP ljzerman, JA Ribeiro, U Eisel, AM Sebastião and HWGM Boddeke

Neuropsychopharmacology (2008) 33, 2789; doi:I 0.1038/npp.2008.92

Correction to: Neuropsychopharmacology (2008) 33, 2237-2250; doi:10.1038/sj.npp.1301612; published online 7 November 2007

In this article, there were errors in Figure 2. The correct figure is given below. a
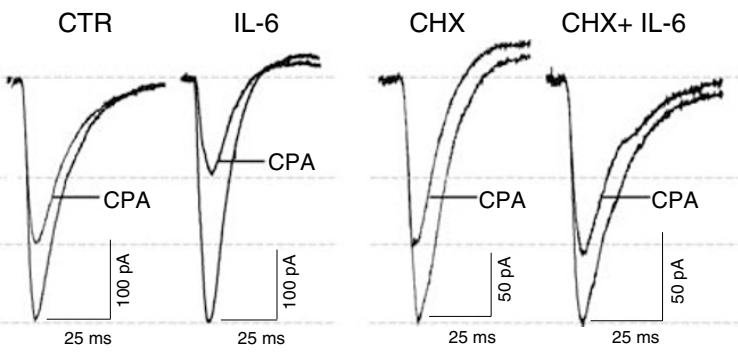

b

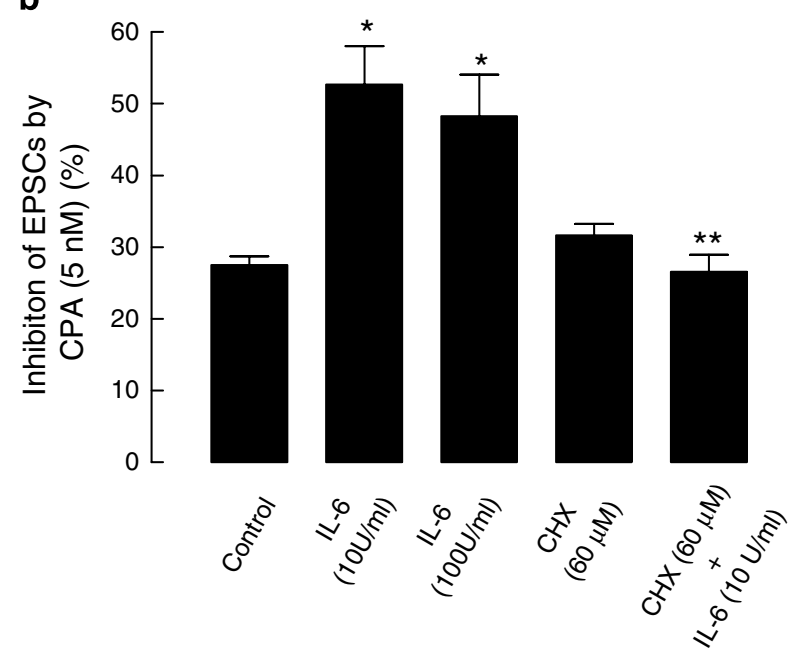

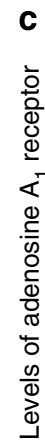

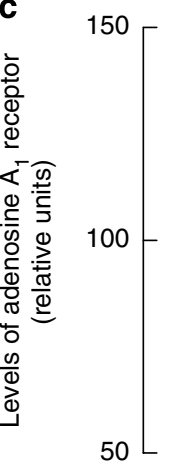

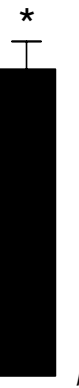

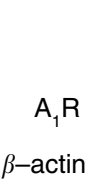

CTR L-6

$A, R$

$43 \mathrm{kDa}$ 